\title{
A COMPARATIVE STUDY ON THE EFFECT OF SOLVENTS ON THE PHYTOCHEMICAL PROFILE AND BIOLOGICAL POTENTIAL OF ORMOCARPUM COCHINCHINENSE AUCT. NON (LOUR.) MERRILL
}

\author{
A. HANNAH HEPSIBAH, G. JEYA JOTHI* \\ Department of Plant Biology and Biotechnology, Loyola College, Chennai 600034, Tamil Nadu, India \\ Email: gjjothiloyola@gmail.com
}

Received: 09 Sep 2016 Revised and Accepted: 05 Nov 2016

\begin{abstract}
Objective: Plants contain different classes of phytochemicals which have different levels of solubility in solvents, based on their polarity. Hence, this study aims to compare the effects of various solvents on the phytochemical profile and biological potential of Ormocarpum cochinchinense. The present study is the first to evaluate the antifungal activity of the plant.
\end{abstract}

Methods: The sequential extraction was carried out using two sets of solvent systems namely hexane, ethyl acetate, ethanol and chloroform, acetone, methanol. The extracts were subjected to standard phytochemical analysis, antimicrobial activity by disc diffusion method against eight bacteria and six fungi and antioxidant activity by 2, 2-diphenyl-1-picrylhydrazyl (DPPH) assay.

Results: Varied range of phytochemicals was found in the extracts. Acetone extract was rich in phenolic compounds, whereas terpenoids were extracted only in methanol. Acetone extracts showed highest antibacterial activity with a maximum zone of 14.5 mm against Shigella flexineri whereas ethyl acetate extract showed the best antifungal activity with the highest zone of inhibition of 12 mm against Trichophyton menta agrophytes. Hexane and chloroform extracts did not show any antimicrobial activity. For DPPH assay, the ethanol extracts showed the highest percentage inhibition of $92.87 \%$.

Conclusion: The present investigation on the plant $O$. cochinchinense has proved that the selection of solvent for extraction should be based on the target compounds and their bioactivity and concludes that acetone was the best for the extraction of antibacterial compounds and ethyl acetate for antifungal compounds whereas, ethanol was the best for extracting antioxidant compounds in 0 . cochinchinense.

Keywords: Phytochemistry, Antimicrobial activity, Disc diffusion, Antioxidant activity, DPPH assay, Ormocarpum cochinchinense

(c) 2017 The Authors. Published by Innovare Academic Sciences Pvt Ltd. This is an open access article under the CC BY license (http://creativecommons.org/licenses/by/4. 0/) DOI: http://dx.doi.org/10.22159/ijpps.2017v9i1.15126

\section{INTRODUCTION}

Plants are great reservoirs of phytochemicals which possess diverse therapeutic properties. Phytochemicals from medicinal plants protect against many chronic degenerative diseases [1]. This is the reason why plants have been studied extensively over the years for their various therapeutic potentials namely antimutagenic, antimicrobial, antioxidant, anticancer, etc., [2]. Apart from therapeutic purpose, phytochemicals are used as precursors for the synthesis of many drugs and about $80 \%$ of present day medicines are directly or indirectly obtained from plants [3].

The important steps in isolating a biologically active phytochemical from plants are extraction, isolation and characterization of the bioactive compound. Extraction is a very crucial step. The selection of solvent systems is based on the compounds that are targeted [4]. During extraction, the solvents solubilize the compounds of similar polarity by diffusing into the solid plant tissue. Plants are usually air dried to remove water content in order to attain a constant weight before extraction. A good solvent should have low toxicity, easy to evaporate, preservative action, inability to cause complex or dissociation of extract, should not interfere with the bioassay [5].

Hospitals Acquired Infection (HAI) is the major cause of death and disability for patients. The rate of deaths due to HAI is up to $25 \%$ in developing countries. Healthcare-associated infections in developing countries are 2 to 20 times higher than in developed countries. In India catheters and lung infections are believed to be the primary source of infection and organisms like Klebsiella, Pseudomonas and Enterococci are predominant. Pneumonia is most common in intensive surgical units. The antibiotic resistance of some commonly used medications is still a therapeutic problem which medicinal plants have the potential to resolve [2] because phytochemicals from plants have a different mechanism of action compared to that of conventional antibiotics and this could be of great help in the treatment of resistant microbes [6].

Free radicals are continuously synthesised in our human body which leads to oxidative stress and can damage lipids, proteins, carbohydrates and DNA [7]. Human cells are constantly exposed to free radicals which lead to several diseases like heart disease, stroke and cancer [2]. Plant based dietary antioxidants are believed to have an important role in the maintenance of human health because our endogenous antioxidants provide insufficient protection against the constant and unavoidable challenge of reactive oxygen species. Phytochemical antioxidants have the ability to neutralise the free radicals or reactive oxygen species or oxidants responsible for the onset of cell damage. Synthetic antioxidants are found to be harmful to health [8].

In developing countries like India, the majority of the population are dependent on traditional medicine for the treatment of various diseases [9]. Moreover, India is one of the largest producers of medicinal herbs and the potential of many higher plants remains to be unexplored in this country [10], at the same time there is a rapid rate of plant extinction and there exists a fear that the rich source of useful phytochemical structures which could be synthesized chemically can be lost forever before their use could be explored [5].

Ormocarpum cochinchinense (Tamil: Elumbotti) which belongs to the family Fabaceae has been used by traditional healers for a long time. The bark and leaves are used for healing bone fracture by the Irula tribes [11]. The leaves are eaten fresh or prepared into a medicated candy (lehiyam) to cure chest pain. The decoction of the root is a valuable remedy for rheumatic fever [12]. The leaves are used for nervous pain. The roots are considered as tonic and stimulant and 
are used in the treatment of lumbago. An application preparation used by rubbing the root bark in oil is used for the treatment of paralysis [13].

Some of the pharmacological properties such as bone fracture healing activity [14] antioxidant activity of the leaf fraction [15] and antibacterial properties of leaves [16] of this plant have been reported.

Hence, this study was an attempt to narrow down on the best solvent for separation and isolation of active compound from the leaf of Ormocarpum cochinchinense by comparing two solvent systems consisting of three solvents each, of increasing polarity for their phytochemical profile, antibacterial, antifungal and antioxidant activities.

\section{MATERIALS AND METHODS}

\section{Collection and identification of plant}

The plant $O$. cochinchinense was collected from the Thiruvannamalai Hills of Tamilnadu, India and was identified by the taxonomist Dr. G. Jeya Jothi and the voucher specimen (LCH 320) was deposited in the Department of Plant Biology and Biotechnology, Loyola College, Chennai.

\section{Chemicals and reagents}

All solvents used for extraction purpose were purchased from Merk, Germany. The chemicals and reagents used for phytochemistry were bought from Himedia, Mumbai, India.

\section{Preparation of leaf extracts}

The leaves were washed and dried under shade. The moisture free leaves were ground into powder and stored in air tight containers for further use. The powdered plant sample was sequentially extracted using 2 sets of solvents namely hexane, ethyl acetate, ethanol and chloroform, acetone, methanol. The extracts were dried to remove the solvents and weighed. The solvent-free extracts were subjected to phytochemical analysis, antimicrobial activity by disc diffusion method and antioxidant activity by DPPH assay.

\section{Microbial culture}

The following organisms were selected for antimicrobial activity, gram positive bacterial pathogens, such as Bacillus subtilis (ATCC 441), Staphylococcus epidermidis (MTCC 3615), Micrococcus luteus (ATCC 4698), Enterococcus durans (P502) and gram negative bacterial pathogens namely, Enterobacter aerogenes (MTCC 111), Pseudomonas aeruginosa (ATCC 27853), Proteus vulgaris (MTCC 1771), Shigella flexneri (MTCC 1457), and the fungal pathogens were Candida albicans (MTCC 227), Candida kursei, Candida tropicalis, Malassezia pachyderatus, Aspergillus flavus, Trichophyton mentagrophytes (66/01). All the cultures were obtained from the department of microbiology, Christian Medical College, Vellore, Tamil Nadu, India.

\section{Phytochemical evaluation of the extracts}

The qualitative phytochemical analysis was done for all the extracts. Standard procedures for alkaloids, flavonoids, phenols, tannins, terpenoids, phytosterols and saponins were followed [17-19].

\section{Antimicrobial activity-disc diffusion method}

Antimicrobial activity was done using disc diffusion method [20]. All the extracts were dissolved in Dimethyl Sulfoxide (DMSO). Three different concentrations $(2500 \mu \mathrm{g}, 1500 \mu \mathrm{g}$ and $500 \mu \mathrm{g}$ per disc) of the extracts were evaluated. $20 \mathrm{ml}$ of sterile Mueller hinton agar (Himedia, Mumbai, India) for bacteria and $20 \mathrm{ml}$ of sabouraud dextrose agar (Himedia, Mumbai, India) for fungi were poured onto Petri plates. The organisms were swabbed onto the medium. $25 \mu \mathrm{L}$ of the extracts were loaded onto the sterile discs and placed on the inoculated Petri plates. The plates were left for $30 \mathrm{~min}$ for proper diffusion of the samples. The plates were incubated for $24 \mathrm{~h}$ at $37^{\circ} \mathrm{C}$ for bacteria and $48 \mathrm{~h}$ at $27^{\circ} \mathrm{C}$ for fungi. The antimicrobial zones formed were measured in millimetres and the results were tabulated. DMSO was taken as a negative control, and ampicillin/sulbactam $(10 / 10 \mu \mathrm{g})$ (Himedia, Mumbai, India) was taken as positive control for bacteria and clotrimazole $(10 \mu \mathrm{g})$ and fluconazole $(10 \mu \mathrm{g})$ (Himedia, Mumbai, India) for fungi.

\section{Determination of relative percentage inhibition (RPI)}

The relative percentage inhibition was calculated for all the extracts with respect to the positive control. The formula used is as follows [21]

$$
\mathrm{RPI}=\frac{100(\mathrm{X}-\mathrm{Y})}{(\mathrm{Z}-\mathrm{Y})}
$$

Where $\mathrm{X}$ is the total area of inhibition of the test extract; $\mathrm{Y}$ is the total area of inhibition of the solvent and $\mathrm{Z}$ is the total area of inhibition of the standard drug.

The Total area of inhibition was calculated using the formula:

Area $=\pi r^{2}$; Where $r$ is the radius of the zone of inhibition.

\section{DPPH scavenging activity}

The antioxidant activity of the extracts was evaluated by DPPH scavenging activity assay [22]. $1 \mathrm{ml}$ of solution of DPPH (Hi-media, Mumbai) solution ( $0.3 \mathrm{mmol}$ ) was added to $2 \mathrm{ml}$ of the extracts of different concentrations. The concentrations of the extracts were $2500 \mu \mathrm{g}, 2000 \mu \mathrm{g}, 1500 \mu \mathrm{g}, 1000 \mu \mathrm{g}$ and $500 \mu \mathrm{g}$. The reaction mixture was kept in the dark for $30 \mathrm{~min}$ and the absorbance was measured at $517 \mathrm{~nm}$ with a spectrophotometer. The percentage inhibition was calculated using the formula:

$\%$ inhibition $=\{$ Absorbance of control-Absorbance of sample $/$ Absorbance of control\} x 100

DPPH solution without the sample was taken as blank and ascorbic acid was taken as standard with concentrations ranging from $100 \mu \mathrm{g}$ to $500 \mu \mathrm{g}$.

\section{Statistical analysis}

All analysis was repeated thrice and the results were presented as mean \pm SD.

\section{RESULTS}

\section{Percentage yield and phytochemical analysis}

The percentage yield of all the extracts was calculated and was found to be $0.638 \%$ for hexane, $3.37 \%$ for chloroform, $1.30 \%$ for ethyl acetate, $1.32 \%$ for acetone, $0.93 \%$ for ethanol and $5.86 \%$ for methanol. All the six extracts were subjected to phytochemical analysis, and the results were tabulated (table 1). Alkaloids, flavonoids were present in methanol, acetone, ethyl acetate and ethanol extracts. Saponins, phenols and tannins were present in ethyl acetate, acetone, ethanol and methanol extracts. Methanol extract alone contained terpenoids. Phytosterols were present in hexane, chloroform, ethyl acetate and acetone extracts.

Table 1: Results of phytochemical analysis of $O$. cochinchinense leaf extracts

\begin{tabular}{|c|c|c|c|c|c|c|c|}
\hline S. No. & Phytochemicals & $\mathbf{H}$ & $\mathbf{C}$ & EA & A & $\mathbf{E}$ & $\mathbf{M}$ \\
\hline 1 & Alkaloids & - & - & +++ & ++ & ++ & +++ \\
\hline 2 & Flavonoids & - & - & + & ++ & +++ & + \\
\hline 3 & Phenols & - & - & + & +++ & ++ & + \\
\hline 4 & Tannins & - & - & + & +++ & +++ & ++ \\
\hline 5 & Terpenoids & - & - & - & - & - & +++ \\
\hline 6 & Phytosterols & ++ & +++ & + & + & - & - \\
\hline 7 & Saponins & - & - & + & ++ & +++ & +++ \\
\hline
\end{tabular}

Note: H-Hexane; C-Chloroform; EA-Ethyl acetate; A-Acetone; M-Methanol; (-) Absence; (+) Presence; (++) Moderate concentration; (+++) High concentration. 


\section{Antimicrobial activity}

All the six extracts were tested for their antimicrobial activity against eight bacteria and six fungi and the results were tabulated (table 2 and table 3 ). The hexane and chloroform extracts did not show any activity against any of the microbes tested.

\section{Antibacterial activity}

The acetone extracts showed highest antibacterial activity followed by ethyl acetate extract. The ethanol and methanol extracts showed moderate activity. Acetone extract showed the highest zone of inhibition of $14.5 \mathrm{~mm}$ against Shigella flexineri; it also showed zones of $13.5 \mathrm{~mm}$ against Enterobacter aerogenes, $13 \mathrm{~mm}$ against Bacillus subtilis and Micrococcus luteus and Pseudomonas aerogenosa. Ethyl acetate showed a maximum zone of $13 \mathrm{~mm}$ against Proteus vulgaris followed by a zone of $12 \mathrm{~mm}$ against Enterococcus durans.

\section{Antifungal activity}

Ethyl acetate extract showed the best activity with the highest zone of inhibition of $12 \mathrm{~mm}$ against Trichophyton menta agrophytes and a zone of $11.5 \mathrm{~mm}$ against Candida tropicalis followed by a zone of $11 \mathrm{~mm}$ against Candida albicans and Aspergillus flavus. Acetone extract showed a maximum zone of 10 $\mathrm{mm}$ against Malassezia pachyderatus.

Table 2: Antibacterial activity of various concentrations of the leaf extracts of $O$. cochinchinense compared with the antibiotic ampicillin/sulbactam

\begin{tabular}{|c|c|c|c|c|c|c|c|c|c|}
\hline Solvent & $\begin{array}{l}\text { Concentra- } \\
\text { tion }\end{array}$ & $\begin{array}{l}\text { Bacillus } \\
\text { subtilis }\end{array}$ & $\begin{array}{l}\text { Staphylococcus } \\
\text { epidermis }\end{array}$ & $\begin{array}{l}\text { Micrococcus } \\
\text { luteus }\end{array}$ & $\begin{array}{l}\text { Enterococcus } \\
\text { durans }\end{array}$ & $\begin{array}{l}\text { Enterobacter } \\
\text { aerogenes }\end{array}$ & $\begin{array}{l}\text { Pseudomonas } \\
\text { aerogenosa }\end{array}$ & $\begin{array}{l}\text { Proteus } \\
\text { vulgaris }\end{array}$ & $\begin{array}{l}\text { Shigellaflexiner } \\
i\end{array}$ \\
\hline \multirow{3}{*}{$\begin{array}{l}\text { Ethyl } \\
\text { acetate }\end{array}$} & $2500 \mu \mathrm{g}$ & $10.00 \pm 0.00$ & $8.00 \pm 0.10$ & $12.00 \pm 0.50$ & $10.00 \pm 0.20$ & $11.00 \pm 0.05$ & $12.00 \pm 0.50$ & $11.50 \pm 0.05$ & $12.00 \pm 0.00$ \\
\hline & $1500 \mu \mathrm{g}$ & $9.60 \pm 0.17$ & $7.96 \pm 0.05$ & $11.06 \pm 0.11$ & $8.90 \pm 0.36$ & $10.66 \pm 0.28$ & $9.50 \pm 0.10$ & $10.50 \pm 0.50$ & $11.00 \pm 0.50$ \\
\hline & $500 \mu \mathrm{g}$ & $8.46 \pm 0.05$ & $7.60 \pm 0.17$ & $10.33 \pm 0.28$ & $8.56 \pm 0.40$ & $9.50 \pm 0.20$ & $9.00 \pm 0.00$ & $9.50 \pm 00$ & $9.96 \pm 0.25$ \\
\hline \multirow[t]{3}{*}{ Acetone } & $2500 \mu \mathrm{g}$ & $13.00 \pm 0.00$ & $9.50 \pm 0.00$ & $13.00 \pm 0.00$ & $11.50 \pm 0.00$ & $13.50 \pm 0.00$ & $13.00 \pm 0.10$ & $11.00 \pm 0.05$ & $14.50 \pm 0.00$ \\
\hline & $1500 \mu \mathrm{g}$ & $10 \pm 0.20$ & $9.23 \pm 0.25$ & $12.00 \pm 0.05$ & $11.00 \pm 0.10$ & $12.00 \pm 0.20$ & $12.00 \pm 0.00$ & $11.00 \pm 0.00$ & $12.50 \pm 0.05$ \\
\hline & $500 \mu \mathrm{g}$ & $9.03 \pm 0.15$ & $8.33 \pm 0.28$ & $11.40 \pm 0.69$ & $8.40 \pm 0.55$ & $10.50 \pm 0.50$ & $9.50 \pm 0.00$ & $9.50 \pm 0.00$ & $10.40 \pm 0.17$ \\
\hline \multirow[t]{3}{*}{ Ethanol } & $2500 \mu \mathrm{g}$ & $9.50 \pm 0.00$ & $7.00 \pm 0.00$ & $9.00 \pm 0.00$ & $9.50 \pm 0.0 .05$ & $11.00 \pm 0.50$ & $10.50 \pm 0.00$ & $9.50 \pm 0.00$ & $10.00 \pm 0.20$ \\
\hline & $1500 \mu \mathrm{g}$ & $8.50 \pm 0.00$ & $6.90 \pm 0.10$ & $7.50 \pm 0.00$ & $9.31 \pm 0.16$ & $10.00 \pm 0.20$ & $9.50 \pm 0.00$ & $8.50 \pm 0.50$ & $9.00 \pm 0.00$ \\
\hline & $500 \mu \mathrm{g}$ & $7.93 \pm 0.11$ & $6.76 \pm 0.15$ & $6.91 \pm 0.23$ & $8.61 \pm 0.10$ & $8.50 \pm 0.10$ & $8.00 \pm 0.00$ & $7.63 \pm 0.15$ & $7.33 \pm 0.28$ \\
\hline \multirow[t]{3}{*}{ Methanol } & $2500 \mu \mathrm{g}$ & $9.50 \pm 0.00$ & $7.50 \pm 0.00$ & $9.00 \pm 0.00$ & $10.00 \pm 0.00$ & $11.00 \pm 0.10$ & $11.50 \pm 0.20$ & $7.50 \pm 0.10$ & $10.50 \pm 0.05$ \\
\hline & $1500 \mu \mathrm{g}$ & $8.50 \pm 0.00$ & $7.00 \pm 0.00$ & $7.36 \pm 0.63$ & $9.00 \pm 0.50$ & $10.00 \pm 0.25$ & $9.00 \pm 0.20$ & $7.00 \pm 0.20$ & $9.36 \pm 0.32$ \\
\hline & $500 \mu \mathrm{g}$ & $7.50 \pm 0.00$ & $6.86 \pm 0.15$ & $6.96 \pm 0.15$ & $8.90 \pm 0.10$ & $7.50 \pm .00$ & $7.90 \pm 0.10$ & $6.76 \pm 0.25$ & $7.50 \pm 0.50$ \\
\hline AMP/SUB & $10 / 10 \mu \mathrm{g}$ & $11.50 \pm 0.00$ & $21.50 \pm 0.00$ & $7.50 \pm 0.01$ & $10.50 \pm 0.50$ & $7.00 \pm 0.10$ & $10 \pm 0.05$ & $18.5 \pm 0.00$ & $7.5 \pm 0.02$ \\
\hline
\end{tabular}

Note: Values are expressed as mean $\pm \mathrm{SD}(\mathrm{n}=3)$

Table 3: Antifungal activity of various concentrations of the leaf extracts of 0 . cochinchinense compared with the standards clotrimazol and flucanazole

\begin{tabular}{|c|c|c|c|c|c|c|c|}
\hline Extract & Concentration & $\begin{array}{l}\text { Candida } \\
\text { albicans }\end{array}$ & $\begin{array}{l}\text { Candida } \\
\text { kursei }\end{array}$ & $\begin{array}{l}\text { Candida } \\
\text { tropicalis }\end{array}$ & $\begin{array}{l}\text { Malassezia } \\
\text { pachyderatus }\end{array}$ & $\begin{array}{l}\text { Aspergillus } \\
\text { flavus }\end{array}$ & $\begin{array}{l}\text { Trichophyton } \\
\text { mentagrophytes }\end{array}$ \\
\hline Ethyl & $2500 \mu \mathrm{g}$ & $11.00 \pm 0.50$ & $9.00 \pm 0.00$ & $11.50 \pm 0.00$ & $10.00 \pm 0.10$ & $11.00 \pm 0.00$ & $12.00 \pm 0.00$ \\
\hline \multirow[t]{2}{*}{ acetate } & $1500 \mu \mathrm{g}$ & $8.90 \pm 0.36$ & $7.66 \pm 0.76$ & $10.00 \pm 0.00$ & $8.00 \pm 0.00$ & $9.23 \pm 0.30$ & $10.41 \pm 0.38$ \\
\hline & $500 \mu \mathrm{g}$ & $7.33 \pm 0.28$ & $7.00 \pm 0.50$ & $8.58 \pm 0.38$ & $6.76 \pm 0.25$ & $8.05 \pm 0.22$ & $8.63 \pm 0.23$ \\
\hline \multirow[t]{3}{*}{ Acetone } & $2500 \mu \mathrm{g}$ & $9.00 \pm 0.20$ & $09.00 \pm 0.10$ & $9.50 \pm 0.00$ & $10.00 \pm 0.00$ & $9.50 \pm 0.10$ & $7.50 \pm 0.00$ \\
\hline & $1500 \mu \mathrm{g}$ & $8.23 \pm 0.25$ & $8.00 \pm 0.00$ & $8.80 \pm 0.26$ & $8.00 \pm 0.00$ & $8.50 \pm 0.50$ & $7.00 \pm 0.00$ \\
\hline & $500 \mu \mathrm{g}$ & $6.46 \pm 0.25$ & $7.20 \pm 0.00$ & $7.50 \pm 0.50$ & - & - & - \\
\hline \multirow[t]{3}{*}{ Ethanol } & $2500 \mu \mathrm{g}$ & $7.50 \pm 0.00$ & $8.00 \pm 0.10$ & $9.50 \pm 0.00$ & $8.50 \pm 0.20$ & $9.50 \pm 0.10$ & $9.00 \pm 0.00$ \\
\hline & $1500 \mu \mathrm{g}$ & $6.76 \pm 0.25$ & $7.00 \pm 0.00$ & $7.50 \pm 0.00$ & $7.73 \pm 0.11$ & $8.31 \pm 0.16$ & $7.63 \pm 0.15$ \\
\hline & $500 \mu \mathrm{g}$ & - & - & - & - & $7.33 \pm 0.15$ & - \\
\hline \multirow[t]{3}{*}{ Methanol } & $2500 \mu \mathrm{g}$ & $8.50 \pm 0.11$ & $7.50 \pm 0.10$ & $8.50 \pm 0.00$ & $8.50 \pm 0.00$ & $9.00 \pm 0.00$ & $7.00 \pm 0.50$ \\
\hline & $1500 \mu \mathrm{g}$ & $7.96 \pm 0.15$ & $6.40 \pm 0.00$ & $7.5 \pm 0.00$ & $7.20 \pm 0.00$ & $8.31 \pm 0.16$ & - \\
\hline & $500 \mu \mathrm{g}$ & $7.20 \pm 0.20$ & - & $6.93 \pm 0.11$ & - & - & - \\
\hline Clotrimazol & $10 \mu \mathrm{g}$ & $15.00 \pm 0.50$ & $12.00 \pm 0.00$ & $11.00 \pm 0.20$ & - & - & - \\
\hline Flucanazole & $10 \mu \mathrm{g}$ & - & - & - & $12.50 \pm 0.00$ & $22.00 \pm 0.00$ & $23.50 \pm 0.00$ \\
\hline
\end{tabular}

Note: Values are expressed as mean $\pm \mathrm{SD}(\mathrm{n}=3)$.; (-) No activity.

\section{Relative percentage inhibition (RPI)}

The relative percentage inhibition was calculated for all the extracts with respect to the positive control, and the results were represented as bar diagrams (fig. 1 and fig. 2).

For antibacterial activity, the acetone extract showed the highest RPI compared to all the extracts against Shigella flexneri (193.33) Enterobacter aerogenes (192.85), Micrococcus luteus (173.33), Enterococcus durans (160.70), Pseudomonas aeruginosa (130) and
Bacillus subtilis (113.04). The ethyl acetate extract showed maximum activity against Proteus vulgaris (62.14).

In the case of fungal pathogens, Ethyl acetate extract showed maximum RPI compared to other extracts. It showed maximum activity against Candida tropicalis (104.54), followed by Malassezia pachyderatus (86.95), Candida kursei (75), Candida albicans (73.33), Trichophyton menta agrophytes (51.07) and Aspergillus flavus (50). 


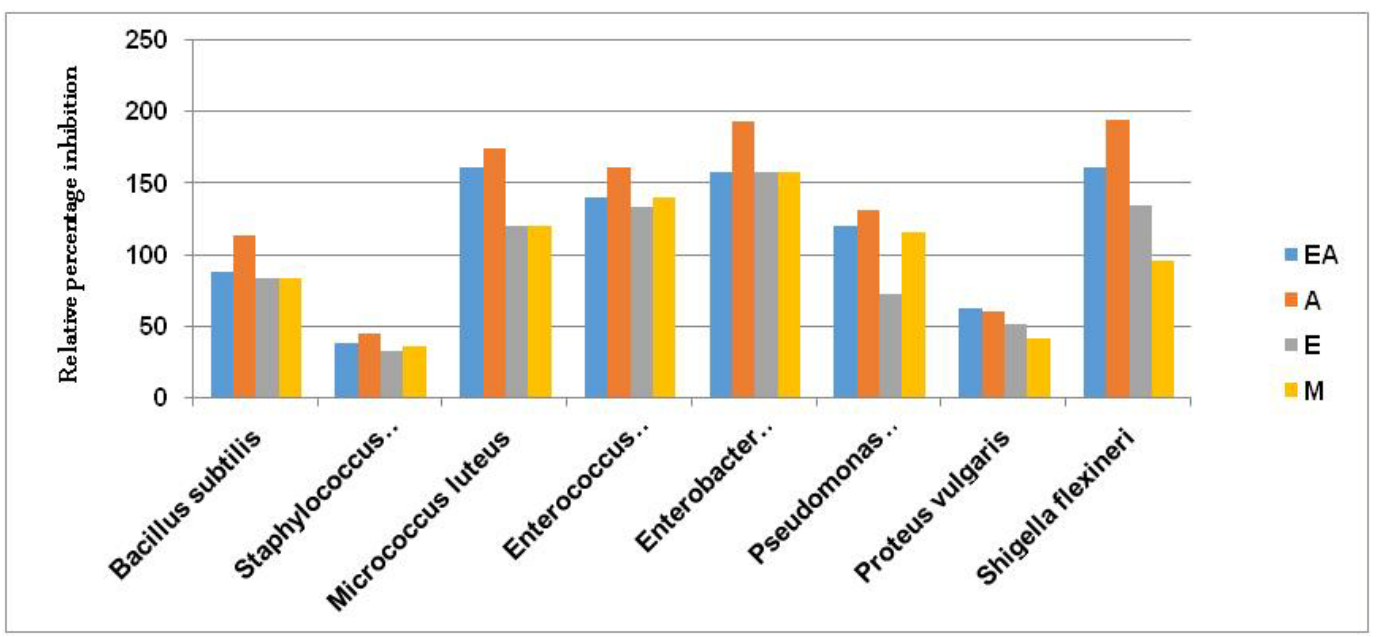

Fig. 1: Relative percentage inhibition of the extracts against the bacterial pathogens Note: H-Hexane; C-Chloroform; EA-Ethyl acetate; A-Acetone; M-Methanol

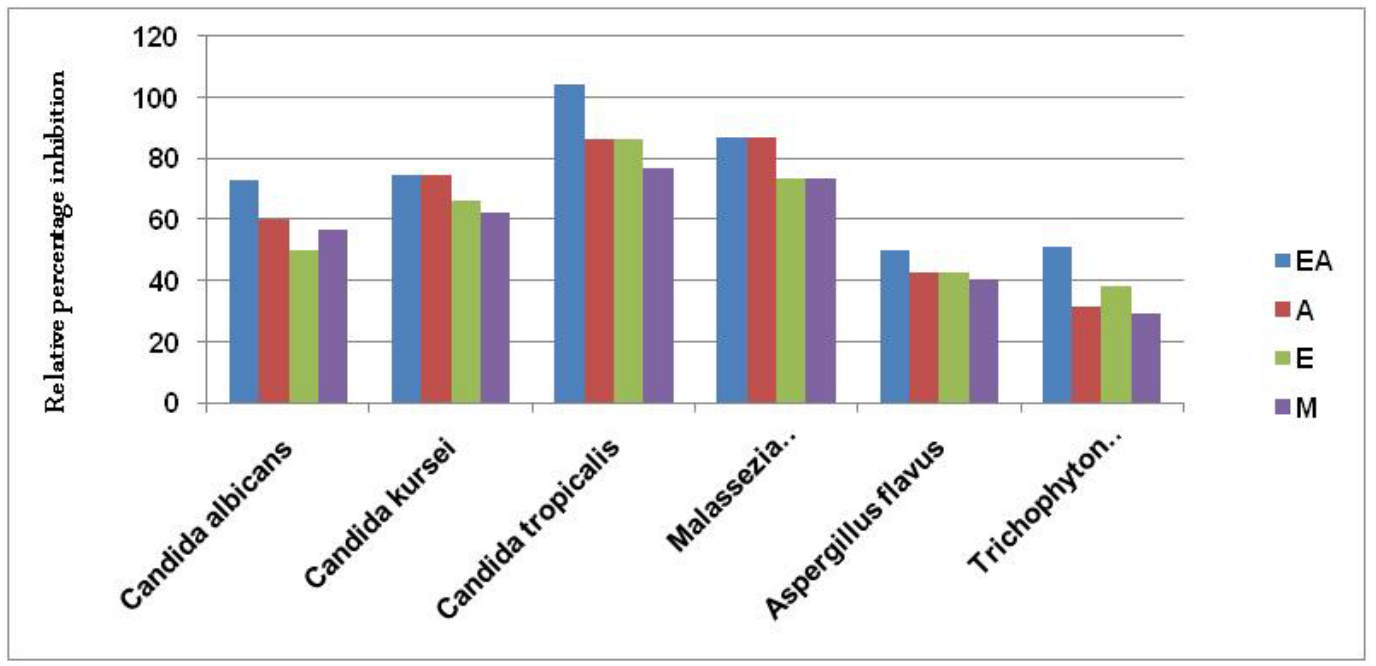

Fig. 2: Relative percentage inhibition of the extracts against the fungal pathogens Note: H-Hexane; C-Chloroform; EA-Ethyl acetate; A-Acetone; M-Methanol

\section{Antioxidant activity}

The chloroform (57.52\%) and hexane (45.88\%) extracts showed very little percentage inhibition even at higher concentrations.
Among the extracts, ethanol extract showed the highest percentage inhibition of $92.87 \%$ followed by ethyl acetate showing $90.47 \%$, acetone which showed $86.61 \%$, and methanol $(76.40 \%)$.

Table 4: Percentage inhibition of various concentrations of the leaf extracts of $O$. cochinchinense and standard ascorbic acid

\begin{tabular}{|c|c|c|c|c|c|c|c|c|c|}
\hline \multirow[t]{2}{*}{ S. No. } & \multicolumn{7}{|c|}{$\%$ inhibition of the extracts } & \multicolumn{2}{|c|}{$\%$ inhibition of ascorbic acid } \\
\hline & Concentration & $\mathbf{H}$ & $\mathbf{C}$ & EA & $\mathbf{A}$ & $\mathbf{E}$ & $\mathbf{M}$ & Concentration & \%Inhibition \\
\hline 1. & $500 \mu \mathrm{g}$ & - & - & $65.01 \pm 2.58$ & $76.88 \pm 1.33$ & $80.47 \pm 0.66$ & $30.30 \pm 0.20$ & $100 \mu \mathrm{g}$ & $58.62 \pm 0.53$ \\
\hline 2. & $1000 \mu \mathrm{g}$ & - & $18.71 \pm 2.50$ & $78.08 \pm 1.15$ & $78.75 \pm 0.22$ & $82.39 \pm 0.49$ & $53.98 \pm 0.20$ & $200 \mu \mathrm{g}$ & $69.19 \pm 0.78$ \\
\hline 3. & $1500 \mu \mathrm{g}$ & $34.36 \pm 2.97$ & $20.46 \pm 0.78$ & $86.64 \pm 2.63$ & $81.84 \pm 0.77$ & $86.60 \pm 0.10$ & $69.32 \pm 0.54$ & $300 \mu \mathrm{g}$ & $77.27 \pm 0.71$ \\
\hline 4. & $2000 \mu \mathrm{g}$ & $36.12 \pm 1.14$ & $38.97 \pm 4.43$ & $89.51 \pm 0.55$ & $83.08 \pm 0.12$ & $89.68 \pm 0.51$ & $72.23 \pm 0.25$ & $400 \mu \mathrm{g}$ & $87.00 \pm 0.69$ \\
\hline 5. & $2500 \mu \mathrm{g}$ & $46.83 \pm 1.81$ & $58.76 \pm 4.67$ & $90.82 \pm 0.42$ & $86.90 \pm 0.53$ & $92.63 \pm 0.19$ & $76.97 \pm 0.18$ & $500 \mu \mathrm{g}$ & $95.34 \pm 0.54$ \\
\hline
\end{tabular}

Note: H-Hexane; C-Chloroform; EA-Ethyl acetate; A-Acetone; M-Methanol; (-) indicates the absence of inhibition.

\section{DISCUSSION}

In the present study, two different solvent systems consisting of different solvents of varied polarities were used for extraction, which yielded difference in the phytochemical profiles and biological activities of the extracts.

The hexane and chloroform solvents showed the presence of phytosterols alone, displayed no antimicrobial activity against the tested pathogens and marginal antioxidant activity. The highest antibacterial activity was displayed by acetone extract which was abundant in phenols and tannins.

Moreover, maximum antifungal activity was observed in ethyl acetate extract which was rich in alkaloids. The ethanol extracts showed best antioxidant activity and contained a high amount of flavonoids, tannins and saponins. 


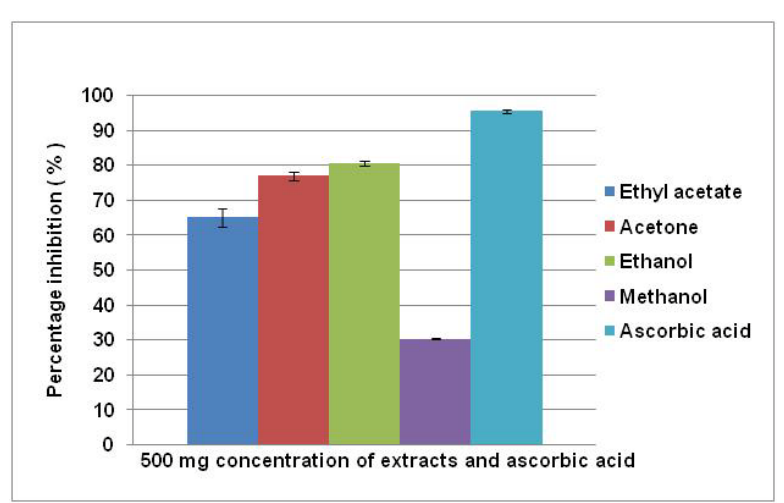

Fig. 3: Percentage inhibition of 500 $\mu$ g of the leaf extracts of $O$. cochinchinense in comparison with ascorbic acid

Note: Results are displayed as mean $\pm \mathrm{SD}(n=3)$ with standard error bars

Compared to an earlier study, where chloroform extract contained varied phytochemicals and showed significant antioxidant activity [15], the chloroform extract in this study contained sterols alone and showed very less antioxidant activity. In earlier studies on the antioxidant activity of $O$. cochinchinense methanol, chloroform and ethyl acetate extracts showed more activity than ethanol rather in the present study ethanol tops the chart followed by acetone and ethyl acetate [15]. This study is the first to evaluate the antifungal activity of $O$. cochinchinense.

In the present study sequential extraction was done. The reason for performing serial extraction is to ensure that a wide range of compounds with different polarity can be extracted [23]. Using solvents of various polarities in an extraction process is essential in order to understand the effect of solvent and extraction efficiency [24]. Hexane mainly extracts pigments [25] and chloroform is said to be the best solvent for extraction of non-polar biological active compounds [23].

The active compounds of $O$. cochinchinense are mainly mid-polar to polar compounds since hexane and chloroform extracts failed to show any activity. Phenols, flavonoids and tannins were found to be abundant in acetone extract, which might be the reason for its high antimicrobial activity and antioxidant activity. Earlier studies have shown that aqueous acetone is said to be better for extraction of tannins and other phenolics [23]. The ethanol extract also contained a high amount of flavonoids and tannins which would have contributed to its antioxidant activity. Phenolic acids, flavonoids and tannins are the main dietary phenolic compounds which provide protection against pathogens and predators. Antioxidant activity of phenolic compounds is due to their ability to scavenge free radicals, donate hydrogen atoms or electrons or chelate metal cations [26]. Saponins were observed to be high in ethanol and methanol extracts. Saponins have antimicrobial properties, and earlier studies have showed that methanol can extract a high amount of saponins from leaves [23]. The methanol extract was found to contain a high amount of alkaloids. Alkaloids play a major role in antiinflammatory properties hence methanol extract could possibly possess anti-inflammatory activity.

\section{CONCLUSION}

From the present study, it can be concluded that the active compounds of Ormocarpum cochinchinense are only extracted in polar solvents since hexane and chloroform extracts failed to show any activity. However, acetone can be employed to extract compounds of antimicrobial property, whereas for the extraction of antifungal compounds ethyl acetate can be used. Moreover, ethanol can be employed to extract compounds with antioxidant potential.

The systematic study of medicinal plants is the need of the hour and has gained importance in modern day medicine. Hence, it is necessary to standardise the methods of analysis in order to obtain reproducible results in the future. Therefore an attempt was made by the authors to standardise the extraction method for antimicrobial and antioxidant analysis. The next step would be to employ the right solvent system according to the target compound to be isolated.

\section{CONFLICT OF INTERESTS}

Declared none

\section{REFERENCES}

1. Jimaima Lako V, Craige Trenerry, Mark Wahlqvist, Naiyana Wattanapenpaiboon, Subramanium Sotheeswaran, Robert Premier. Phytochemical flavonolscarotenoids and the antioxidant properties of a wide selection of Fijian fruit, vegetables and other readily available foods. Food Chem 2007;100:1727-41.

2. Chukwujekwu JC, Amoo SO, Van Staden J. Antimicrobial, antioxidant, mutagenic and antimutagenic activities of Distephanus angulifolius and Ormocarpum trichocarpum. J Ethnopharmacol 2013;148:975-9.

3. Myers. Phytochemical methods (a guide to modern techniques to plant analysis), Chapman and Hall; 1982.

4. Sasidharan S, Chen Y, Saravanan D, Sundaram KM, Yoga Latha L. Extraction, isolation and characterization of bioactive compounds from plants extracts. Afr J Tradit Complementary Altern Med 2011;8:1-10.

5. Das K, Tiwari RKS, Srivastava DK. Techniques for evaluation of medicinal plant products as antimicrobial agent: current methods and future trends. J Med Plants Res 2010;4:104-11.

6. Simoes M, Bennett RN, Rosa EA. Understanding antimicrobial activities of phytochemicals against multidrug resistant bacteria and biofilms. Nat Prod Rep 2009;26:746-57.

7. Arora R, Gill NS, Kaur S, Jain AD. Phytopharmacological evaluation of ethanolic extract of seeds of Abrus precatorius Linn. J Pharmacol Toxicol 2011;6:580-8.

8. Krishnaiah D, Sarbatly R, Bono A. Phytochemical antioxidants for health and medicine-A move towards nature. Biotechnol Mol Biol Rev 2007;1:97-104.

9. Konaté K, Yomalan K, Sytar O, Brestic M. Antidiarrheal and antimicrobial profiles extracts of the leaves from Trichili aemetica Vahl. (Meliaceae). Asian Pac J Trop Biomed 2015;5:242-8.

10. Ahmedulla M, Nayar MP. Red data book of Indian plants. Botanical Survey of India, Calcutta; 1999.

11. Rathakrishnan T. Traditional agricultural practices: Applications and technical implementations, New India Publishing; 2009.

12. Subodh Kapoor. The Indian Encyclopedia, Genesis Publishing Pvt. Ltd; 2002.

13. Markham CR. Travels in Peru and India: While superintending the collection of Chinchona plants and seeds in South America, and their introduction into India; 2012.

14. Dinesh Kumar M, Maria John KM, Karthik S. The bone fracture healing potential of Ormocarpum cochinchinense methanolic extract on albino Wistar rats. J Herbs Spices Med Plants 2013;19:1-10.

15. Sivakumar T, Gajalakshmi D. In vitro antioxidant and chemical constituents from the leaves of Ormocarpum cochinchinense Elumbotti. Am J Plant Physiol 2013;8:114-22.

16. Hannah Hepsibah A, Jeya Jothi G. In vitro antibacterial activity and phytochemical analysis of Ormocarpum cochinchinense extracts on nosocomial infection causing bacteria. Asian J Pharm Clin Res 2014;8:113-6.

17. Sofowora A. Medicinal plants and traditional medicine in Africa. Spectrum Books Ltd; 1993.

18. Trease GE, Evans WC. Pharmacognosy. Brailliar Tiridel and Macmillan Publishers, London; 1989.

19. Harborne JB. Phytochemical methods: A guide to modern techniques of plant analysis. Chapman and Hall, London; 1973.

20. Murray PR, Baron EJ, Pfaller MA, Tenover FC, Yolke RH. Manual of clinical microbiology. ASM, Washington, D; 1995.

21. Dharajiya D, Patel P, Patel M, Moitra N. In vitro antimicrobial activity and qualitative phytochemical analysis of Withania somnifera (L.) Dunal extracts. Int J Pharm Sci Rev Res 2014; 27:349-54.

22. Stephen IS, Sunil C, Duraipandiyan V, Ignacimuthu S. Antidiabetic and antioxidant activities of Toddalia asiatica (L.) Lam. leaves in streptozotocin-induced diabetic rats. J Ethnopharmacol 2012; 143:523. 
23. Ncube NS, Afolayan AJ, Okoh AI. Assessment techniques of antimicrobial properties of natural compounds of plant origin: current methods and future trends. Afr J Biotechnol 2008; 7:1797-806

24. Jigna Parekh, Sumitra Chanda. Antibacterial and phytochemical studies on twelve species of Indian medicinal plants. Afr J Biomed Res 2007; 10:175-81.

25. Sasidharan S, Chen Y, Saravanan D, Sundaram KM, Yoga Latha L Extraction, isolation and characterization of bioactive compounds from plants extracts. Afr J Tradit Complementary Altern Med 2011;8:1-10.
26. Nagendran Balasundram, Kalyana Sundram, Samir Samman Phenolic compounds in plants and agri-industrial by-products: antioxidant activity, occurrence, and potential uses. Food Chem 2006; 99:191-203.

\section{How to cite this article}

- A Hannah Hepsibah, G Jeya Jothi. A comparative study on the effect of solvents on the phytochemical profile and biologica potential of Ormocarpum cochinchinense auct. non (Lour.) Merrill. Int J Pharm Pharm Sci 2017;9(1):67-72. 